\title{
MENGKOBINASIKAN GAMES DENGAN STRATEGI BUZZ GROUPS UNTUK MENINGKATKAN PEMAHAMAN MAHASISWA PADA KELAS GRAMMAR
}

\author{
Dwi Taurina Mila W \\ dwimeela@gmail.com \\ Universitas Abdurachman Saleh Situbondo
}

\begin{abstract}
The final goal of this study is to know the effectiveness of learning methods that combine games with the Buzz Groups strategy to improve students' ability in Grammar classes at Faculty of letters at Abdurachman Saleh Situbondo University. Buzz Groups is a discussion group that discusses a topic and exchange ideas to solve a problem, where the same discussion method in each meeting will saturate students so that a combination of games is needed so the discussion is not boring. The combination of games and strategy was chosen because Grammar class is a subject that tends to be boring because the material is rather difficult for students, so it needs a way to keep them excited, happy and play an active role in learning activities. This study is a classroom action research that is made in one research cycle. The data in this study will be obtained during learning activities, where the existence of this research is expected to be able to assist teachers / lecturers in teaching English so that the methods used are more varied and the learning targets are expected to be achieved.
\end{abstract}

Key Words: Games, Buzz Groups, Pembelajaran Grammar

\section{PENDAHULUAN}

Kegiatan diskusi yang dilakukan secara monoton dan terus menerus dapat membuat kegiatan pembelajaran menjadi membosankan, walaupun media yang digunakan sudah bervariasi. Oleh karena itu diperlukan games agar siswa dapat bermain dan belajar sehingga kegiatan diskusi menjadi menyenangkan. Terutama pada mata kuliah yang cenderung tidak disukai seperti mata kuliah Grammar. Selain itu games juga dapat meningkatakan kerjasama kelompok.

Seorang guru harus benar-benar paham dan mengerti akan karakteristik dan kepentingan siswa yang dia handel. Pemilihan strategi haruslah sesuai dengan kebutuhan siswa agar siswa tidak bosan dan pasif sehingga tujuan pembelajaran akan tercapai. oleh sebab itu, penelitian ini bertujuan untuk meneliti proses pembelajaran menggunakan strategi buzz groups yang dikombinasikan dengan games pada kelas Grammar di Fakultas Sastra Inggris Abdurachman Saleh Situbondo. 
Selanjutnya penelitian ini menggunakan pendekatan dengan menggunakan metode penelitian tindakan kelas (Classroom Action Research) untuk melihat perubahan peningkatan kemampuan Grammar mahasiswa sebagai sumber data penelitian. Metode peneltian tindakan kelas bersifat partisipan. Maksudnya adalah bahwa orang yang melakukan tindakan harus juga terlibat dalam proses penelitian dari awal seperti yang dikemukakan oleh Kemmis dan Mc Taggart (1998) yaitu:

Action research is a kind of self-reflective enquiry which is undertaken by participants in any situations which is aimed to improve rationality and educational practices after those practices are carry out.

Penelitian strategi pembelajaran telah dilakukan oleh beberapa peneliti sebelumnya. Sukris Sutiyatno pada tahun 2016 melakukan penelitian strategi pembelajaran dengan menggunakan metode Cooperative Learning yang menitik beratkan pada kemampuan membaca. Dalam penelitiannya Sutiyatno menggunakan pendekatan experiment dengan menggunakan kelas kontrol sebagai perbandingan. Penelitian lain yang juga masih berhubungan dengan penelitian ini dilakukah oleh Yabarmase (2014) dimana penelitiannya menggunakan strategi fishbowl untuk meningkatkan kemampuan berbicara bahasa Inggris pada siswa pada program kelas bahasa. Pada penelitiannya Yabarmase menggunakan penelitian tindakan kelas dengan melakukan pre-test-posttest untuk mengukur tingkat keberhasilannya.

Penelitian ini berbeda dengan penelitian sebelumnya karena penelitian ini lebih spesifik pada penelitian yang berfokus pada tata bahasa mahasiswa dengan menggunakan metode buzz groups yang mengkolaborasikan games. Oleh sebab itu, dapat dirumuskan masalah penelitian yaitu bagaimana meningkatkan kemampuan berbahasa Inggris mahasiswa pada kelas grammar dengan asumsi bahwa melalui metode buzz groups yang dikombinasikan dengan games akan membuat siswa paham akan materi yang diberikan dan kegiatan diskusi menjadi menyenangkan. 
Sementara itu, untuk membatasi penelitian ini maka peneliti memberi batasan penelitian hanya pada penggunaan strategi buzz groups dan strategi ini dikombinasikan dengan penggunaan games. Penelitian ini melalui satu tahapan siklus penelitian. Pertemuan kedua dilakukan untuk membuktikan bahwa hasil tindakan yang dilakukan bukanlah kebetulan dan hanya sebagai penguatan. Penelitian ini dilakukan pada kelas Grammar semester 2 dengan mata kuliah Basic Grammar di Fakultas Sastra Universitas Abdurachman Saleh Situbondo.

Penelitian ini bertujuan untuk mengetahui keefektifan strategi buzz groups dengan mengkombinasikan games dalam upaya peningkatan pemahaman bahasa Inggris mahasiswa sastra Unars. Penelitian ini juga memberikan kontribusi terhadap ilmu pengetahuan yaitu pada dunia pendidikan.

\section{METODE PENELITIAN}

Rancangan penelitian dalam penelitian ini menggunakan penelitian tindakan kelas. Hakikat penelitian tindakan kelas (classroom action research) terletak pada adanya tindakan dalam situasi yang alami untuk memecahkan permasalahan-permasalahan praktis atau meningkatkan kualitas praktik.

Langkah-langkah yang akan dilakukan adalah sebagai berikut:

\section{(a) Perencanaan}

Rencana tindakan yang akan dilakukan pada penelitian ini adalah dengan menyusun rancangan tindakan peningkatan kemampuan tata bahasa dalam bahasa Inggris melalui kegiatan berikut.

a) menyusun rancangan tindakan berupa strategi kegiatan pembelajaran: hal yang menjadi fokus perhatian meliputi perumusan tujuan pembelajaran, kegiatan pembelajaran, dan evaluasi,

b) menyiasati pembelajaran dengan cara menyiapkan sarana dan prasarana pendukung proses pembelajaran, dan

c) menyusun alat perekam data meliputi: video recorder, pedoman untuk melakukan observasi, pedoman wawancara, dan pedoman penilaian analisis strategi pembelajaran. 


\section{(b) Pelaksanaan/Tindakan}

Kegiatan pelaksanaan tindakan yang dilakukan pada tahap ini sebagai berikut:

a) melaksanakan pembelajaran melalui strategi buzz groups dengan mengkombinasikan games;

b) mengadakan observasi pada siswa dan guru saat tindakan dilakukan dengan menggunakan pedoman serta alat yang sudah disiapkan; dan

c) melakukan refleksi terhadap tindakan yang dilakukan; hasil refleksi yang dilakukan dimanfaatkan untuk perbaikan, penyempurnaan kegiatan pembelajaran siswa dengan strategi yang digunakan pada pertemuan selanjutnya.

\section{Setting dan Subjek Penelitian}

Setting penelitian dilaksanakan di Fakultas Sastra Universitas Abdurachman Saleh Situbondo. Kegiatan penelitian ini akan dilaksanakan selama 4 x 45 menit meliputi 2 kali pertemuan dengan 1 kali siklus. Subjek dari penelitian ini adalah mahasiswa semester II, dimana mata kuliah pada semester II ini adalah mata kuliah Basic English Grammar. Pada semester ini mahasiswa belajar tentang dasar-dasar tata bahasa bahasa Inggris.

\section{Data dan Sumber Data}

1. Data

Pada penelitian ini, data yang digunakan adalah rangkaian proses kegiatan pada saat pembelajaran yang terjadi di dalam kelas saat dilaksanakan strategi buzz groups dengan mengkombinasikan games. Perubahan tingkah laku siswa juga merupakan data penelitian ini.

2. Sumber Data

Data diperoleh langsung dari hasil observasi, interview, evaluasi, dan nilai posttest.

Penelitian ini akan dilaksanakan antara bulan Juni 2018 sampai Agustus 2018. 


\section{Teknik Analisa Data}

Data yang diperoleh melalui observasi dan interview didiskusikan bersama mitra dan dibandingkan antara pertemuan pertama dan pertemuan kedua. Hasil posttest dari masing masing pertemuan dibandingkan untuk mempertegas peningkatan dari hasil observasi.

\section{Prosedur Penelitian}

\section{Persiapan Penelitian}

Menurut Kemmis dan McTaggart (dalam Rochiati, 2005:55) rancangan penelitian tindakan kelas terdiri dari beberapa tahap kegiatan, meliputi: perencanaan/rancangan, tindakan, observasi, dan refleksi. Berdasarkan hal tersebut, dapat diuraikan secara rinci langkah-langkah yang digunakan dalam penelitian ini sebagai berikut.

\section{Prasiklus}

Dalam pembelajaran berdasarkan pengamatan peneliti, diketahui bahwa strategi pembelajaran yang dipilih dan digunakan monoton dan membosankan. Jadi diperlukan adanya kombinasi lain yang membuat kegiatan pembelajaran menjadi menyenangkan.

\section{Pelaksanaan Penelitian}

Penelitian ini akan dilaksanakan dengan 1 siklus, dengan dimulai perencanaan, pengamatan, observasi, dan refleksi. jika siklus pertama dianggap masih belum berhasil maka akan diadakan tambahan siklus.

\section{(a) Perencanaan (plan)}

Kegiatan pelaksanaan tindakan yang akan dilakukan pada tahap ini sebagai berikut:

\section{Siklus I}

1. Tahap Perencanaan

Meliputi pembuatan RPP, pemilihan topik yang akan diputar melaui media, serta menyusun alat evaluasi.

2. Tahap Pelaksanaan 
(b) Tindakan (act)

\section{Pertemuan Pertama}

Meliputi proses kegiatan belajar mengajar dengan strategi buzz groups. Dengan langkah-langkah pembelajaran sebagai berikut:

a. pendahuluan

1. Memberikan tujuan dan tema pembelajaran kepada mahasiswa.

2. Membagi kelompok besar menjadi kelopok kecil yang terdiri dari 2 atau 3 orang

b. kegiatan inti

1. Memberikan topik pembelajaran yang telah disiapkan.

2. Meminta siswa untuk mendiskusikan topik diskusi yang diberikan.

3. Mengkombinasikan games dalam kegiatan diskusi

4. Meminta mahasiswa untuk mendiskusikan jawaban permasalahan dalam kelompoknya

5. Setelah 15 menit kemudian meminta setiap kelompok untuk membacakan hasil diskusinya secara bergantian atau menggunakan game dalam pembahasannya.

6. Menarik kesimpulan.

c. penutup

Mahasiswa diminta untuk mengerjakan soal posttest.

\section{(c) Pengamatan (observe)}

Hal-hal yang diamati selama pelaksanaan tindakan adalah:

1. Aktifitas selama model pembelajara.

2. Perubahan tingkah laku mahasiswa dalam kegiatan diskusi kelompok.

3. Kemampuan siswa dalam menyampaikan pikiran dan pendapatnya

(d) Refleksi (reflect)

Pada tahap ini dilakukan evaluasi untuk mengetahui perkembangan peningkatan kemampuan mahasiswa, kemudian mengoreksi hasil posttest. Hasil posttest pada pertemuan pertama akan dibandingkan pada hasil posttest pada pertemuan kedua. Hal ini dilakukan untuk membuktikan bahwa hasil 
tersebut bukan sebuah kebetulan, tetapi merupakan hasil dari penerapan strategi pembelajaran yang dilakukan.

\section{Pertemuan ke dua}

langkah-langkah pembelajaran pada pertemuan ke dua sama seperti pada pertemuan pertama, tetapi pada pertemuan kedua ini topik materi berbeda dengan kombinasi game yang berbeda pula yang disesuaikan dengan materi. Pada tahan refleksi pada pertemuan ini yaitu:

- Dosen memberikan komentar serta tanya jawab terhadap penampilan masing-masing kelompok;

- Guru memberikan motivasi kepada siswa;

- Guru menggunakan games lain untuk membuat siswa bersemangat;

- Guru memberikan hadiah bagi kelompok terbaik.

Selanjutnya dilakukan tahap revisi dari hasil tes dan observasi yang dilakukan, hal ini digunakan sebagai dasar pengambilan kesimpulan. Jika pada siklus ini masih banyak siswa yang belum mencapai ketuntasan minimal maka dilanjutkan pada siklus selanjutnya.

\section{(c) Observasi (observe)}

Keberhasilan tindakan dari segi proses dikatakan berhasil apabila terlaksana dengan baik sesuai dengan yang direncanakan (rencana pembelajaran), sedangkan dari segi hasil, tindakan dikatakan berhasil apabila sudah mendapat nilai $\geq 72$ atau mencapai ketuntasan belajar.

Apabila kedua aspek tersebut berhasil, maka penggunaan strategi pembelajaran Buzz Groups dengan mengkobinasikan games dinilai berhasil.

\section{(d) Refleksi (reflect)}

Peneliti mempertimbangkan hasil PTK dari berbagai kriteria dan berdasarkan refleksi, peneliti melakukan revisi. Refleksi merupakan pemahaman ulang terhadap pembelajaran yang telah dilakukan. Refleksi diadakan setiap satu tindakan berakhir. Refleksi ini berupa evaluasi yang telah dilakukan dan pemunculan saran untuk pembelajaran berikutnya. 


\section{HASIL PENELITIAN DAN PEMBAHASAN}

Penelitian ini dilaksanakan dalam satu siklus yang terdiri dari dua pertemuan dan setiap pertemuan berlangsung selama 90 menit. Penelitian ini dilaksanakan pada tanggal 16 dan 20 Juli 2018. Berikut ini deskripsi pelaksanaan penelitian tindakan kelas dalam Basic English Grammar yang mengkombinasikan games dengan strategi buzz groups di semester 2 Fakultas Sastra Unars.

\section{Pertemuan I}

Pada pertemuan pertama memiliki tahapan yang meliputi: perencanaan, tindakan dan pengamatan, serta refleksi.

a. Perencanaan

Perencanaan penelitian dilakukan dengan tujuan merencanakan tindakan yang dilakukan dalam pembelajaran grammar untuk meningkatkan pemahaman grammar dan motivasi belajar mahasiswa. Tahapan perencanaan yang dilakukan dalam penelitian pertemuan I meliputi persiapan materi yang akan didiskusikan, games yang digunakan, dan media pendukung yang akan dipakai.

b. Tindakan

Pada pertemuan I dilaksanakan pada hari senin, 16 Juli 2018 pada pukul 18.00 - 19.30 WIB di semester 2 ruang fakultas sastra Unars. Dosen memberikan pengantar tentang materi yang akan dipelajari. Materi yang dibahas disini adalah materi penggunaan used to. Mahasiswa diminta untuk membentuk kelompok. Setelah itu mahasiswa diminta untuk membentuk kelompok diskusi yang terdiri dari 2 orang setiap kelompok diminta untuk mengamati bentuk dari penggunaan used to dan fungsinya. Diskusi dilakukan selama 10 menit. Kemudian setelah mahasiswa selesai berdiskusi, perwakilan dari setiap kelompok maju ke depan untuk mempersentasikan hasil temuannya. Disini games digunakan. Mahasiswa diminta berhitung dan mengingat angka yang mempresentasikan dirinya. Setelah Dosen akan menyebutkan satu angka dan angka yang disebutkan harus diteruskan oleh mahasiswa yang di sebutkan angkanya. Contoh kegiatan: 
Dosen : One

Mahasiswa 1 : Four

Mahasiswa 2 : six

Mahasiswa 3 : eee....eight dst.

Jika mahasiswa lambat meneruskan angka maka kelompok itu yang akan maju mempersentasikan hasil diskusinya. Begitu seterusnya sampai mahasiswa menemukan kesimpulan yang benar dari hasil diskusi.

Selanjutnya guru meminta siswa untuk mengerjakan soal-soal selama 30 menit. Pembahasan dilakukan dengan cara meminta siswa untuk membaca soal dan menjawabnya satu persatu berurutan, setiap orang satu soal dan bergantian. Jika jawaban salah maka mahasiswa yang lain akan memeperbaiki. Dosen memimpin diskusi ini. Dosen akan secara langsung mengetahui berapa nilai siswa.

Pada akhir pertemuan dosen akan merefleksi hasil diskusi dengan cara menyimpulkan materi hari itu dan menanyakan mahasiswa apakah mereka memahami materi yang dipelajari.

c. Observasi

Observasi dilaksanakan untuk mengamati kegiatan diskusi mahasiswa. Bagaimana mereka berdiskusi dan membuat suara buzz. Mahasiswa terlihat serius dalam berdiskusi dan membuat suara buzz bising seperti kelopok lebah yang sedang bekerja. Pada kegiatan pembahasan presentasi melalui metode games terlihat mahasiswa senang dan bersemangat.

d. Refleksi

Berdasarkan observasi yang dilakukan pada pertemuan I menunjukkan bahwa selama pelaksanaan pembelajaran grammar dengan metode buzz group dan games menunjukkan bahwa masih terdapat kekurangan yang harus diperbaiki pada pertemuan selanjutnya. Namun mahasiswa sudah terlihat lebih bersemangat dalam mengikuti kegiatan pembelajaran. Adapun hambatan yang terjadi pada saat pembelajaran yaitu:

1) Mahasiswa masih agak sulit dikondisikan sehingga waktu tidak efisien. 
2) Mahasiswa masih kebingungan dalam mengerjakan tugas karena kurang fokus pada instruksi dosen.

\section{Pertemuan II}

Pertemuan II dilaksanakan dengan tujuan merencanakan tindakan yang akan dilaksanakan sebagai perbaikan berdasarkan refleksi dan kekurangan yang ada pada siklus sebelumnya.

b. Perencanaan

Pelaksanaan Pertemuan II dilakukan dengan tujuan merencanakan tindakan yang akan dilaksanakan sebagai perbaikan berdasarkan refleksi dan kekurangan yang ada pada siklus sebelumnya.

c. Tindakan

Pada pertemuan II dilaksanakan pada hari jumat, tanggal 20 Juli 2018 pukul 18.00 - 19.30 WIB di semester 2 ruang fakultas sastra Unars. Pada pertemuan kedua ini materi yang diberikan adalah penggunaan artikel in, on, dan at. Tahap pertama dosen meminta siswa untuk membuat kelompok kecil yang terdiri dari 2 orang setiap kelompok. Kemudian meminta mahasiswa untuk mendiskusikan materi yang ada di buku. Selama 10 menit dan mempersentasikan tentang penggunaannya secara bergantian melaui perwakilan setiap kelompok. Kelompok lain dapat menanyakan materi jika tidak sependapat atau menanyakan sesuatu yang tidak dimengerti. Karena disini ada 4 kelompok diskusi maka setiap kelompok hanya mempersentasikan satu bahasan artikel.

Kemudian tahapan kedua, dosen meminta siswa untuk mengerjakan latihan soal. Secara individu. Namun setelah itu membahasnya dalam kelompok kecil lagi. Disini games yang digunakan adalah wheel game, dimana dosen membuat gambar roda sebanyak kelompok diskusi kemudian memberi angka pada setiap jari-jari roda untuk di isi sesuai dengan nomer jawaban soal. Jawaban berisi tentang artikel in, on atau at. Pembahasan jawaban soal dibaca oleh setiap mahasiswa. Untuk jawaban yang salah pada setiap group akan diberi lingkaran. Group yang rodanya paling banyak lingkaran salahnya akan terlihat. Seperti bunga. Group yang paling sedikit 
lingkaranya yang keluar sebagai group terbaik. Dosen memberi reward bagi group terbaik.

e. Observasi

Pada pertemuan kedua ini ditemukan bahwa mahasiswa lebih bersemangat lagi dalam mengikuti kegiatan pembelajaran. mereka sampai lupa bahwa waktu pembelajaran telah berakhir, namun mereka masih asik bercanda membahas hasil belajar mereka dan mereka berkata bahwa mereka sangat menikmati sekali kegiatan belajar grammar kali ini. Siswa sudah mulai memahami langkah-langkah kegiatan yang dipakai oleh dosen sehingga waktu yang digunakan lebih efektif.

d. refleksi

Terjadi peningkatan motivasi mahasiswa dalam kegiatan pembelajaran. Dari hasil interview menunjukkan bahwa mahasiswa senang dan termotivasi untuk mengikuti kegiatan pembelajaran mata grammar dengan metode buzz. group yang dipadukan dengan game. Mereka juga mengatakan bahwa dengan metode ini mereka lebih memahami materi yang disampaikan.

\section{Peningkatan Hasil Belajar}

Dari hasil nilai pretest disetiap kegiatan ditemukan bahwa nilai target ratarata mata kuliah Basic English Grammar terjadi peningkatan pemahaman disetiap kegiatannya. Dimana nilai mahasiswa sudah lebih dari 72 atau nilai B

\section{KESIMPULAN DAN SARAN}

\section{Kesimpulan}

Berdasarkan penelitian yang telah dilakukan dapat disimpulkan bahwa:

1. Penggunaan strategi Buzz Group yang dikombinasikan games lebih dapat meningkatkan motivasi mahasiswa.

2. Berdasarkan hasil interview yang didapat, mahasiswa menyatakan bahwa mereka lebih bersemangat mengikuti kegiatan pembelajaran melalui diskusi yang digabungkan dengan games.

3. Mahasiswa juga lebih mudah memahami pokok materi yang diberikan 


\section{Saran}

Berdasarkan hasil penelitian, maka peneliti mempunyai beberapa saran:

1. Sebaiknya penggunaan strategi yang dipadukan dengan games digunakan dalam kelas yang mempunyai materi kompleks dan cenderung lebih membosankan agar proses pembelajaran lebih aktif

2. Sebaiknya dosen/guru lebih memotivasi mahasiswa untuk lebih aktif di kelas.

3. Penggunaan metode yang bervariasi oleh dosen/guru dapat menjadi cara untuk meningkatkan keaktifan dan motivasi mahasiswa agar tertarik dalam belajar.

\section{DAFTAR PUSTAKA}

Cross, D. (1992). A Practical Handbook of Language Learning. London: Practice Hall.

Dimyati dan Moedjiono. (1992). Strategi Belajar Mengajar.Depdikbud Dirjen Dikti: Proyek Pembinaan tenaga Kependidikan.

Djamarah, Syaiful Bahri\&Azwan Zain. (2006). Strategi belajar mengajar. Jakarta: Rineka Cipta.

Harmer, J (2001). The Practice of English Languange Teaching Third Edition. England: Pearson Education Limited.

Hasibuan dan Moedjiono. (2004). Proses Belajar Mengajar. Bandung; PT Rosda Karya.

Hisyam dkk. (2008). Strategi pembelajaran Aktif. Yokyakarta: Pustaka Insani Madani.

McCallum, G. P. (1980). 101 Word Games: For students of English as second or foreign language. Oxford: Oxford University Press.

Rasyid, A\&Nur H. (1997). Teaching English as a Foreign Language (TEFL) in Indonesia. Theory, Practice, and Research, Department of English Language.

Read, C. (2009). 500 Activities for the Primary Classroom. Thailand: MacMillan.

Soepono. 2000.Penelitian Tindakan kelas. Yogyakarta: CAPS 
Supriadi. (2006). Penerapan Pembelajaran dengan metode Buzz Groups untuk Meningkatkan Motivasi Belajar Siswa. Skripsi. Jember: FKIP UNEJ

Suprijanto. (2007). Pendidikan Orang Dewasa. Jakarta: PT. Bumi Aksara

Surjadi. (1989). Membuat Siswa Aktif. Bandung: Bandar maju.

Pinandhita, Fitra. (2014). Implementing 3D Animation Film as a Device to Enhance Students' Speaking Skill for 1A Grade Students of IKIP PGRI Madiun. The 61thTeflin. Proceeding.

Tarigan, Djago H.G.(1986). Teknik pengajaran keterampilan Berbahasa. Bandung: Penerbit Angkasa

Trianto. (2007). Model Pembelajaran Inovatif Berorientasi Kontruktivitif. Jakarta: prestasi Pustaka.

Wiriatmadja, Rochiati.(2005).Metode penelitian Tindakan kelas. Bandung: PT. Remaja Rosdakarya. 